\title{
Moral theories
}

\section{The moral philosophy of Maimonides}

\author{
Alexander Broadie University of Glasgow
}

\section{Author's abstract}

Maimonides (1135-1204) wrote extensively on moral philosophical matters. In his three main works, the Commentary on the Mishnah, the Mishneh Torah, and the Guide of the Perplexed, he developed a far-reaching ethical system which is Aristotelian and yet is also greatly dependent upon the Rabbinic tradition. In this paper it is argued that Maimonides presents an effective synthesis of these apparently disparate traditions.

Moses Maimonides (1135-1204) was the greatest Jewish thinker of the Middle Ages. He was also one of the most distinguished physicians of the period and, as we shall see, his work in the latter field deeply influenced his ethical speculations. Those speculations occur in their most systematic form in two great works that he wrote on Jewish law. The context is crucial. Faced with the question of how we should act in a given situation, we should consult the word of God as interpreted by the recognised religious authorities. A good life is a godly life. But Maimonides was heir not only to the rabbinic tradition but also to the writings of Aristotle and to extensive reflections upon them by Muslim philosophers, and his moral philosophy reveals the profound influence that the Muslim Aristotelians had upon him.

He starts from a parallel: 'The doctor who cures bodies needs first to know, in its entirety, the body he is curing and what the parts of the body are, I mean the body of a man. And he needs to know what things make it sick so that they may be avoided and what things make it healthy so that they may be pursued. Similarly, the one who treats the soul and wishes to purify moral habits needs to know the soul in its entirety and its parts, as well as what makes it sick and what makes it healthy.' The term 'soul' here signifies the principle of life in a living organism, and in that sense not only do humans have souls, so also do plants and non-human animals. With this in mind Maimonides speaks of the five parts of the human soul: nutritive, sensitive, imaginative, appetitive, and

\section{Key words}

Virtue; vice; Maimonides. rational. Plants have a nutritive soul, and among the parts of the soul of a non-human animal are the sensitive, imaginative, and appetitive. Which is not to say that the appetitive part of an animal's soul is of precisely the same kind as the appetitive part of a human's, for the rational part of a human soul contributes to the shaping of the appetitive part, whereas the appetitive part of an animal's soul is in no way affected by the animal's power of reason, for it has none.

These facts and many more concerning the nature of the human soul are known by the 'physician of the soul', a kind of wise man who, according to Maimonides, has an important role to play in society: 'Those with sick souls (ie vicious people) who do not recognise their illness but imagine they are healthy or who recognise it but do not submit to medical treatment will meet the fate of a sick man who pursues his pleasures and does not submit to medical treatment - he will undoubtedly perish.' Why will he perish? A crucial ingredient in all moral vices is that they have an essentially civic aspect; they lead to actions which work against the common good. And society has to protect itself, through its legal system, against those who engage in such actions. In addition Maimonides may have in mind his doctrine that salvation does not await the souls of the vicious. I shall return to this point at the end of this paper.

In stressing the civic nature of moral vice, and moral virtue also, Maimonides reveals his Aristotelian heritage. This is further revealed in his account of the relations between virtue and vice. Virtues and vices are classed as character traits, or habits, with each virtue a mean between two extremes, one an excess and the other a deficiency. He gives numerous examples: liberality is the mean between extravagance and miserliness, moderation the mean between lust and insensibility to pleasure, gentleness between irascibility and servility, and modesty between impudence and shyness. It is the fact that people are not born with virtues or vices but develop them by a process of habituation through frequent repetition, that provides the clue to the appropriate treatment of the morally sick: 'Should his soul become sick, he must follow the same course in treating it as in the medical treatment for bodies. For when the body gets out of 
equilibrium, we look to which side it inclines in becoming unbalanced, and then oppose it with its contrary until it returns to equilibrium. When it is in equilibrium, we remove that counterbalance and revert to that which keeps the body in equilibrium. We act in a similar manner with regard to moral habits.' For example, a person who has become miserly should make a practice of extravagance until he has ceased to be miserly, and then he can revert to the virtuous state of liberality.

Maimonides notes in this connection that often a given virtue is closer to one of the corresponding extremes than to the other. For example, liberality is closer to extravagance than to miserliness. 'This subtlety' he asserts 'is the rule of therapy and is its secret'. Since a person can more easily turn from extravagance to liberality than from miserliness to liberality, the extravagant person does not need to perform miserly acts as frequently as a miserly person needs to perform extravagant ones, as a means to recovering the virtuous path of liberality. Likewise, in order to regain his courage, the rash man need perform cowardly acts less often than the cowardly man must perform rash ones. Maimonides concludes: 'This is the rule for the medical treatment of moral habits, so memorise it'.

One implication of this is that the wise man, aware of a tendency he has towards one extreme, will incline towards the opposite extreme as a precaution. Sensing a tendency to lustful action he will tend to actions normally expressive of insensibility to pleasure; this will enable him to retain a moral equilibrium. The wisdom of such behaviour is obvious. The danger, noted by Maimonides, is that an ignorant person, misunderstanding the behaviour of the wise and thinking that insensibility is the path of virtue, will set about afflicting his body and thereby establishing a vicious habit in his soul instead of a virtuous one. Maimonides compares such a person to one who, ignorant of the art of medicine and observing the treatment being given to a deathly sick patient, argues that if the treatment is good for the sick it is even better for the healthy. 'Similarly' says Maimonides 'those with sick souls are undoubtedly so from taking medication while they are healthy' - not quite a description of psychiatrogenic illness since Maimonides is here supposing that the wrong medication was prescribed by the patient, not the doctor.

Maimonides is in general strongly hostile to excessive behaviour - frequent fastings and other abstinences are contrary to our nature which is Godgiven. A person should not act in such a way as wantonly to impair his physical well-being: 'He shall not inhabit caves or mountains, nor wear garments of hair and wool, nor torment his body or make it weary or afflict it. That is forbidden in the tradition which has come down to us.' Plainly such behaviour must be condemned as not in accordance with the mean. It is also contrary to God's law.
This point prompts the question of the relation $\stackrel{8}{\stackrel{1}{2}}$ between Maimonides's rabbinic inheritance and his $\underset{-}{\vec{*}}$ Aristotelianism. He himself saw a harmony between the two. On the one hand we are required to seek the path of virtue by following the mean between excess and deficiency, and on the other hand God's law in various ways requires of us actions which will ensure $\overline{\underline{\bar{\sigma}}}$. our adherence to that same path of virtue. For $\frac{\overline{\bar{c}}}{\overline{\frac{5}{}}}$ example, 'You shall not take revenge nor bear $a \stackrel{\mathbb{\Phi}}{\triangle}$ grudge' [Lev 19, 18] aims at weakening the power of rage and irascibility. 'You shall not see your brother's? ox or his sheep driven away, and hide yourself from? them; you shall surely bring them back to your $\vec{\omega}$ brother' [Deut 22,1] aims at removing the state of avarice. And 'You shall rise before the aged and honour the old man' [Lev 19,32] and 'Honour your father and: your mother' $[E x 20,12]$ aim at removing the state of $\vec{P}$ impudence and instilling that of modesty. Maimonides. offers other examples also, but the point is in any caseo clear. Obedience to God's law promotes virtue.o Neither can there be any surprise in this; the virtuous? behaviour of the citizens of a state tends to promote the well-being of the citizens. And God, as our creator, is concerned about our well-being, and his commandments will of course reflect that concern. Those commandments will therefore teach us how to be virtuous.

Given the close fit between the Aristotelian virtie and God's commandments it is not at all surprising that Maimonides took a dim view of those misunderstanding the carefully regulated behaviour of the wise, heaped afflictions upon themselves, thinkingy to make themselves virtuous thereby. MaimonidesD quotes with approval the Talmudic verse: 'Is what the Torah has prohibited for you not enough, that you? prohibit other things for yourself?' God's commandments themselves represent a perfect mean between extremes, and the ignorant person, by adding his own commandments to God's, inevitably lives by å list which represents an extreme. No wonder he does not achieve virtue.

At least it should be said on behalf of a persoi. ignorant in that way, that he recognises the difficulty os being virtuous; but he has mis-identified the solution As to the difficulty, Maimonides is as alive to that as anyone could be. He writes: 'The perfect man needs to inspect his moral habits continually, weigh his actions and reflect upon the state of his soul every single dayo Whenever he sees his soul inclining towards one of the extremes, he should rush to cure it and not let the evilu state become established by the repetition of a bad action ... he should attend to the defective moral habif in himself and continually seek to cure it, for a max inevitably has defects.' In support of this Maimonides quotes Solomon: 'There is no man who is just upon the earth, and who does only good and does not sin' [Ecct] $7,20]$. One point being made here, which must speak $t \overrightarrow{8}$ people living in any age, is that the struggle for virtue is never won. We can never attain a state at which we can safely relax and say 'Good, now I am virtuous? 
Instead we have a continual struggle to maintain virtue once gained - hence the need for self-vigilance. Maimonides, as is usual with him, offers a medical parallel. He compares the situation to that of the person who always keeps a friendly eye on his physical state, ready to apply treatment whenever his wellbeing suffers; though of course we are not dealing here with morbid pre-occupation with health. That is an extreme and a vice.

We are dealing here with more than a mere parallel, for the link between physical and moral well-being is causal: 'On the basis of this reasoning, the art of medicine is given a very large role with respect to the virtues, the knowledge of God, and attaining true happiness. To study it diligently is among the greatest acts of worship. It is, then, not like weaving and carpentry, for it enables us to perform our actions so that they become human actions, leading to the virtues and the truths.' Of course, this does not imply that one cannot be virtuous unless one is healthy. But there can be no doubt that in general the more serious a person's illness and the more his spiritual, as well as his physical, resources are taken up with the attempt to cope with illness the less easy is it for him to exercise the wide range of civic virtues. Intellectual virtues are also less easily exercised when ill; pain is a great distraction.

Illness is not the only obstacle to virtuous behaviour. Much more obviously, desire can be one. Possession of a contrary desire can ensure that, even if the virtuous act is done, it costs the agent blood. So a distinction can be drawn. Amongst persons who habitually perform virtuous acts there are those whose acts do, and those whose acts do not, regularly accord with their desires. People of the first class are virtuous tout court, and those of the second are said to be continent (or strong-willed, since they have to overcome desire in order to perform virtuous acts). It can be argued that people of the first kind are better since their desires are better directed; this is the position of 'the philosophers' (ie Aristotelians) as reported by Maimonides. But he reports that the sages take the opposite view: 'According to them, someone who craves and strongly desires transgressions is more virtuous and perfect than someone who does not crave them and suffers no pain in abstaining from them. They even said that the more virtuous and perfect an individual is, the stronger is both his craving for transgressions and his pain in abstaining from them.' Here is one point at which the two great traditions which Maimonides inherited appear in clear conflict. He seeks a resolution by the standard mediaeval means of drawing a distinction. There are some things which everyone judges to be bad, such as murder, theft, fraud, harming an innocent person, repaying a benefactor with evil, and degrading one's parents (these are Maimonides's examples). There are, on the other hand, acts which would not be bad were it not for the fact that God's law prohibits them, for example, mixing meat with milk. In the light of this distinction the opinion of the philosophers and that of the sages can both be accepted. For when the philosophers say that a person who acts virtuously in accordance with his desires is better than one who has to overcome contrary desires in order to act virtuously, they have in mind acts whose moral status is universally agreed upon. Thus someone who refuses to steal, and has no desire to steal, is better than one who refuses while yet having the desire; one who repays a benefactor with good and desires to repay him with good, is better than one who, while repaying him with good, yet desires to repay him with evil. On the other hand, when the sages say that the continent man is more virtuous they have in mind acts which are good solely because God has commanded them.

The distinction just made is not however entirely plain sailing. In particular the claim that certain acts which are good are so only because God commanded them, needs to be handled carefully. There was a longstanding disagreement, duly reflected in Maimonides's writings, especially in his great philosophical treatise The Guide of the Perplexed, concerning whether the laws of God are consequent solely upon His will, or are consequent also upon His wisdom and aim at some good. The very clearly expressed view of Maimonides is that all the laws of God are consequent upon His wisdom, even though we do not know in every case what it is about a law that makes it a wise one. However, it is possible to speak in general terms about this matter, even if the details now, and perhaps will always, elude us. 'The Law as a whole aims at two things: the well-being of the soul and the well-being of the body.' As regards the former, this consists of the possession of correct opinions about God and about man's place in creation. And the second is achieved through two things: (i) the prohibition on people acting according to their own will and up to the limits of their power, and (ii) the acquisition by each person of moral qualitites that are useful for life in society so that the affairs of the city are well ordered.

This last point reveals the place of political theory within Maimonides's system. We have two perfections, that of the body and that of the soul. Bodily perfection is physical good health, for which food, shelter, and so on, are required, and they can best be assured through political association. And perfection of the soul cannot be achieved unless perfection of the body is first achieved. As Maimonides puts the point: 'A man cannot cognize an intelligible even when taught to understand it and all the more cannot become aware of it on his own accord, if he is in pain or is very hungry or thirsty or is hot or is very cold. But once the first perfection is achieved it is possible to achieve the ultimate perfection, which is undoubtedly more noble and is the only cause of permanent preservation.' For Maimonides, therefore, the successful governance of a state can make a crucial difference to a person's chance of salvation. The nature of this ultimate perfection of soul to which Maimonides here alludes quickly becomes clear; he sums up his position by quoting Jeremiah: 'Thus saith the Lord: let not the wise man glory in his wisdom, neither let the mighty man glory in his might, let not the rich man 
glory in his riches: but let him that glories glory in this, that he understands and knows Me' [ Fer 9, 22-3].

These words of Jeremiah lie at the heart of Maimonides's moral philosophy and there is no mistaking the urgency of tone when he quotes them. There are, of course, many today for whom those words will have at most a merely aesthetic appeal. But even for those unsympathetic to Jeremiah's words, there is much in Maimonides's ethical theory relating to his account of virtue and vice and the means bym which the one can be promoted and the other banished, which is of interest. His teaching in that area is as? relevant to us today as it was to the twelfth century North African cultural scene which Maimonides did so? much to enrich.

Alexander Broadie is Reader in Philosophy at the University of Glasgow.

\section{News and notes}

\section{Tennent Caledonian and Royal Bank of Scotland Research Fellowships 1989-90}

Applications are invited for these research fellowships for the academic session 1989-90. The fellowships are intended primarily, though not exclusively, for philosophers and political theorists on study leave from their own universities. Appointment is normally for one term and the fellowship carries a travel allowance, accommodation in St Andrews, a room in the Department of Moral Philosophy and access to word-processing facilities.
Further details are available from the Director, Dr John Haldane, Centre for Philosophy and Public Affairs.

Applications, including a cv, a short statement of research intentions or plans, and an indication of the term during which the fellowship would be held, should be submitted to: The Establishments Officer, University of St Andrews, St Andrews, Fife, KY16 9AL 